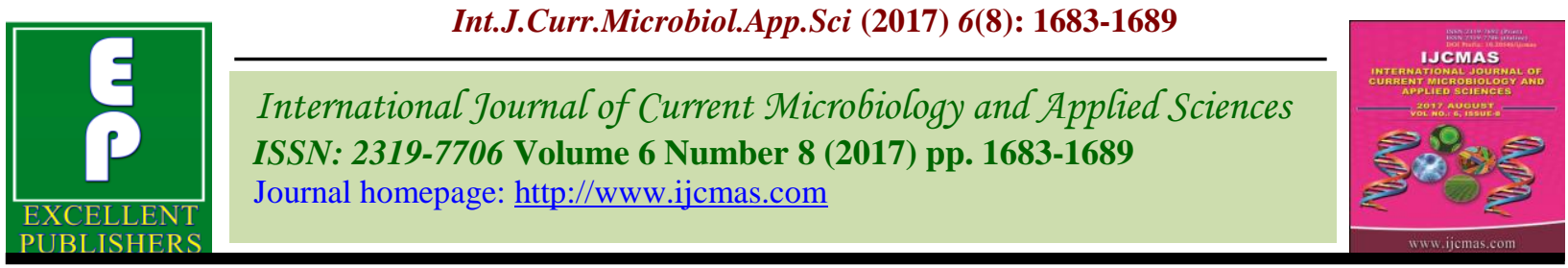

Original Research Article

https://doi.org/10.20546/ijcmas.2017.608.202

\title{
Effect of Municipal Sewage on Soil Biological Properties in the Vicinity of Jaipur City of Eastern Rajasthan, India
}

\author{
S.R. Kumawat*, B.L. Yadav and S.P. Majumdar \\ Department of Soil Science, SKN College of Agriculture, Jobner-303328 \\ SKN Agriculture University, Jobner-Jaipur, Rajasthan 203328, India \\ *Corresponding author:
}

\begin{tabular}{|c|c|}
\hline & A B S T R A C T \\
\hline $\begin{array}{l}\text { Ke y w o r d s } \\
\text { Sewage water, } \\
\text { Heavy metals, } \\
\text { Soil microbial } \\
\text { biomass and Soil } \\
\text { enzyme. }\end{array}$ & \multirow{3}{*}{$\begin{array}{l}\text { An experiment entitled "Effect of municipal sewage on soil properties and build up of } \\
\text { heavy metals in vegetable crops grown in vicinity of Jaipur city" was undertaken with the } \\
\text { aim to assess the suitability of sewage water for irrigation and their effect on the soil } \\
\text { properties. Sewage water samples from Amanishah Nala and tube well were collected and } \\
\text { analysed to Judge their suitability for irrigation. Soil samples from the fields irrigated with } \\
\text { sewage, dilute sewage and tube well water were collected and analysed. The sewage water } \\
\text { from Aminishah Nala contain higher values of metallic cation }(\mathrm{Zn}, \mathrm{Cu}, \mathrm{Fe}, \mathrm{Mn}, \mathrm{Ni}, \mathrm{Pb}, \mathrm{Cd} \\
\text { and } \mathrm{Cr} \text { ), however, the metallic cations } \mathrm{Cu}, \mathrm{Mn}, \mathrm{Ni}, \mathrm{Pb} \text { and } \mathrm{Cd}) \text { content were above the } \\
\text { recommended maximum concentration. The use of sewage water for irrigation in light } \\
\text { textured soil of Jaipur, microbial biomass } \mathrm{C}, \mathrm{N}, \mathrm{P} \text { and alkaline phosphatase and } \\
\text { dehydrogenase activity decreased in sewage irrigated fields. A higher inorganic and } \\
\text { organic loading of sewage water with degradation of soil biological properties under study } \\
\text { call for passing of the sewage water through an effluent treatment plant before being } \\
\text { diverted for irrigation. }\end{array}$} \\
\hline Article Info & \\
\hline $\begin{array}{l}\text { Accepted: } \\
\text { 19 June } 2017 \\
\text { Available Online: } \\
10 \text { August } 2017\end{array}$ & \\
\hline
\end{tabular}

\section{Introduction}

Use of sewage sludge in agriculture is the most convenient practices of sludge disposal. Agriculture can use large and increasing quantities of sludge because it improve soil fertility by increasing the soil organic matter, microbial activity and plant nutrients and by improving the soil physical properties (Stamatiadis et al., 1999). The waste waters are suitable for crop production provided the content of major plant nutrients is high and that of toxic elements is low. Its long term application would affect the physical, chemical and biological properties of soil (Antil, 2012). All the microbially-mediated biochemical reactions involving nutrient cycling are catalyzed by enzyme and depending on their nature and level of contamination, many heavy metals have been found to impede soil enzyme activities to different extents (Yang et al., 2008).

The entry of toxic elements of the heavy metals create serious problem whenever they get accumulate in the environment. Some exceptions were observed and were attributed to the adsorption of these elements by organic materials. Maintenance of a diverse and functioning microbial community is important for soil sustainability. Loss of microbial diversity makes biological systems less able 
to adapt to environmental stresses. Low soil microbial diversity indicates stressed conditions in soil while high diversity is an indicator of a healthy soil (Rao, 2007). The activity of various soil enzymes has been suggested as a measure of microbial activity an early indication of changes brought about by soil management. Soil microorganisms are indeed affected by heavy metals as the result of a multiplicity of interactions that can occur between microbial cells and other environmental constituents. The clay minerals (montmorillonite and kaolinite) protect microorganisms, including bacteria, actionomycetes and filamentous fungi from inhibitory effects of $\mathrm{Cd}$ and the protective ability of clays is correlated with their CEC. Besides this, microbial resistance to heavy metals may also be genetically determined, depending on the ability of some micro organisms to biochemically transform toxic metals and to control cell uptake and permeability. Population of various microorganisms and activities of dehydrogenase and phosphatases enzymes had reduced significantly with the use of contaminated waters for irrigation was also reported by Rao et al., (1993) and Tripathi et al., (2006).

\section{Materials and Methods}

The area under study falls under agro climatic zone III A (semi arid eastern plain zone) of Sanganer tehsil of Jaipur district of Rajasthan and the geographical bearing of the area are $26^{\circ} .49^{\prime}$ to $26^{\circ} 45^{\prime} \mathrm{N}$ (latitude) and $75^{\circ} .46$ to $75^{0} .44 \mathrm{E}$ longitude comprising have four villages. This water from nala normally made available to the farmers along nala in the periphery of $1 \mathrm{~km}$. Sewage effluent water is pumped out to the field by farmers through hose pipe and collect into cemented tank of size $10 \times 10 \times 2 \mathrm{~m}$ (approximately). The collected sewage water applied to vegetable field as such by farmers and some farmers applied sewage water after dilution with tube well water of own in the same tank in equal proportion and irrigated the vegetable crops by field channel viz., Sanganer, Ramsinghpura, Shikarpura and Govindpura. Microbial biomass $\mathrm{C}, \mathrm{N}$ and $\mathrm{P}$ were determined using the fumigation extraction methods (Brookes et al., 1982; Vance et al., 1987; Brookes et al., 1985). Soil samples were conditioned by maintaining moisture to $40 \%$ water holding capacity to measure microbial biomass $\mathrm{C}, \mathrm{N}$ and $\mathrm{P}$. The preconditioned soil samples were fumigated by saturating with liquid ethanol free chloroform $\left(\mathrm{CHCl}_{3}\right)$ in desiccators and stored in the dark room for $24 \mathrm{hr}$ (Srivastava and Singh, 1988). $\mathrm{CHCl}_{3}$ was subsequently removed by repeated evacuation and samples were extracted with $0.5 \mathrm{M} \mathrm{K}_{2} \mathrm{SO}_{4}$ (1:4) for 30 minutes. In the same way, the unfumigated soil samples were also extracted. Organic carbon in the soil extract was measured using the acid dichromate method (Vance et al., 1987). $\mathrm{C}_{\text {mic }}$ was estimated as $\mathrm{BC}=2.64 \mathrm{EC}$, where EC (extractable carbon) is the difference between carbon extracted from fumigated and unfumigated treatments both expressed in the same measurement unit $\mathrm{N}_{\text {mic }}$ was also determined by $\mathrm{CHCl}_{3}$ fumigation method (Brookes et al., 1985) using the same $\mathrm{K}_{2} \mathrm{SO}_{4}$ extract, which was used for $\mathrm{C}_{\text {mic. }}$. The soil extract was analysed for total $\mathrm{N}$ using Kjeldahl digestion method. Soil $\mathrm{N}_{\text {mic }}$ was estimated as $\mathrm{BN}=\mathrm{EN} / 0.54$ (Brookes et al., 1985 and Srivastava and Singh, 1989), where EN (extractable nitrogen) is the difference between $\mathrm{N}$ extracted from fumigated and unfumigated samples Measurement of $\mathrm{P}_{\text {mic }}$ was also done in preconditioned soil samples (Brookes et al., 1982). Soil was fumigated in the same way as that of $\mathrm{C}_{\text {mic }}$ estimation. $\mathrm{P}_{\text {mic }}$ was calculated from the difference between the amount of inorganic $\mathrm{P}(\mathrm{Pi})$ extracted by $0.5 \mathrm{M} \mathrm{NaHCO}_{3}(\mathrm{pH} 8.5)$ from soil fumigated with $\mathrm{CHCl}_{3}$ and unfumigated soil. Inorganic$\mathrm{P}(\mathrm{Pi})$ in the extracts was determined by 
ammonium-molybdate-staneous chloride method (Olsen et al., 1954). $\mathrm{P}_{\text {mic }}$ was then computed as the ratio of $\mathrm{CHCl}_{3}$ release $\mathrm{Pi}$ with a kp value of 0.40 (Brookes et al., 1982 and Srivastava and Singh, 1988) by assuming that $40 \%$ of the $\mathrm{Pi}$ in the soil microbial biomass is rendered extractable as $\mathrm{Pi}$ by $\mathrm{CHCl}_{3}$. Dehydrogenase activity was measured by the method given by Casida et al., (1964).

In the method, the soil samples were incubated with 2, 3, 5- triphenyl tetrazolium chloride at $35^{\circ} \mathrm{C}$ and the production of triphenyl formazan (TPF) was measured on a spectrophotometer at $485 \mathrm{~nm}$. The assay of alkaline phosphatase was carried out according to the method of Tabatabai and Bremner (1969) with borax- $\mathrm{NaOH}$ buffer $(\mathrm{pH}$ 9.4) using $p$-nitrophenyl phosphate disodium salt as substrate at $35^{\circ} \mathrm{C}$.

\section{Results and Discussion}

\section{Biological properties}

\section{Microbial biomass carbon, $P$ and nitrogen}

Microbial biomass plays a key role in the process of soil organic matter dynamics and soil nutrient availability in the agricultural ecosystem.

Soil management practices strongly affect the microbial biomass, particularly the input of carbon substance (Brooks et al., 1990). Result of this study revealed that the amount of microbial biomass $\mathrm{C}, \mathrm{N}$ and $\mathrm{P}$ declined with irrigation with sewage water (Table 2). This reduction in the microbial biomass was due to deleterious effect of heavy metal on microbial cell synthesis which is accumulated in soil by metals contained sewage water (Table 1).

Heavy metal contamination of soils results in long term decease in microbial biomass (Chander and Brookes, 1999a).

Brokes et al., (1986) also found smaller microbial biomass in soil which had received metal contaminated sludge from 1942 to 1961 compared to similar uncontaminated soils. The existence of negative correlation between microbial biomass $\mathrm{C}, \mathrm{N}$ and $\mathrm{P}$ and heavy metal content of soil (Table 4). This is also supports the findings of present investigation (Hassan, 1996 and Jinping et al., 2010).

Table.1 Seasonal variation in heavy metal concentration $\left(\mu \mathrm{g} \mathrm{L}^{-1}\right)$ of sewage, dilute sewage and tube well water during mansoon and winter season

\begin{tabular}{|l|l|l|l|l|l|l|l|}
\hline \multicolumn{2}{|c|}{ S.No } & \multicolumn{2}{c|}{ Sewage } & \multicolumn{2}{c|}{ Dilute Sewage } & \multicolumn{2}{c|}{ Tube well } \\
\cline { 2 - 8 } Parameters & Mansoon & Winter & Mansoon & Ninter & Mansoon & Winter \\
\hline \hline 1 & $\mathrm{Zn}$ & 285.11 & 318.16 & 150.76 & 172.83 & 33.75 & 35.50 \\
\hline 2 & $\mathrm{Cu}$ & 232.41 & 331.51 & 116.38 & 173.65 & 19.90 & 20.78 \\
\hline 3 & $\mathrm{Fe}$ & 3.06 & 3.31 & 1.64 & 1.73 & 0.132 & 0.136 \\
\hline 4 & $\mathrm{Mn}$ & 341.65 & 384.93 & 169.10 & 187.67 & 34.81 & 30.77 \\
\hline 5 & $\mathrm{Ni}$ & 75.78 & 116.63 & 30.12 & 47.72 & $\mathrm{ND}$ & $\mathrm{ND}$ \\
\hline 6 & $\mathrm{~Pb}$ & 403.08 & 473.79 & 199.57 & 232.73 & $\mathrm{ND}$ & $\mathrm{ND}$ \\
\hline 7 & $\mathrm{Cd}$ & 36.08 & 52.39 & 15.47 & 27.76 & $\mathrm{ND}$ & $\mathrm{ND}$ \\
\hline 8 & $\mathrm{Cr}$ & 40.95 & 57.72 & 18.28 & 32.55 & $\mathrm{ND}$ & $\mathrm{ND}$ \\
\hline
\end{tabular}

$\mathrm{ND}=$ Not detected 
Table.2 Effect of sewage, dilute sewage and tube well water on microbial biomass $\left(\mu \mathrm{g} \mathrm{g}^{-1}\right.$ soil) of soil during mansoon and winter season

\begin{tabular}{|c|c|c|c|c|c|c|}
\hline \multirow[t]{2}{*}{ treatments } & \multicolumn{2}{|c|}{$\begin{array}{l}\text { microbial biomass } \mathrm{C} \\
\left(\mu \mathrm{g} \mathrm{g}^{-1} \text { soil }\right)\end{array}$} & \multicolumn{2}{|c|}{$\begin{array}{l}\text { microbial biomass } \mathrm{N} \\
\left(\mu \mathrm{g} \mathrm{g}^{-1} \text { soil }\right)\end{array}$} & \multicolumn{2}{|c|}{$\begin{array}{l}\text { microbial biomass } P \\
\left(\mu \mathrm{g} \mathrm{g}^{-1} \text { soil }\right)\end{array}$} \\
\hline & Pre & Post & Pre & Post & Pre & Post \\
\hline \multicolumn{7}{|c|}{ Mansoon } \\
\hline Sewage & 147.85 & 137.08 & 25.19 & 23.23 & 16.60 & 14.46 \\
\hline SD & 8.87 & 8.07 & 1.51 & 1.38 & 0.98 & 0.86 \\
\hline $\begin{array}{l}\text { Dilute } \\
\text { sewage }\end{array}$ & 165.05 & 156.09 & 26.22 & 26.30 & 15.44 & 15.00 \\
\hline $\mathrm{SD}$ & 9.94 & 8.65 & 1.50 & 1.55 & 0.94 & 0.41 \\
\hline Tube well & 176.15 & 181.62 & 27.25 & 29.38 & 14.28 & 15.53 \\
\hline SD & 10.43 & 9.22 & 1.49 & 1.77 & 0.90 & 0.87 \\
\hline \multicolumn{7}{|c|}{ Winter } \\
\hline Sewage & 140.69 & 129.72 & 23.98 & 22.00 & 13.08 & 11.78 \\
\hline $\mathrm{SD}$ & 7.83 & 7.83 & 1.44 & 1.32 & 0.81 & 0.75 \\
\hline $\begin{array}{l}\text { Dilute } \\
\text { sewage }\end{array}$ & 154.71 & 142.06 & 24.60 & 23.99 & 13.50 & 13.35 \\
\hline SD & 9.16 & 8.21 & 1.47 & 1.44 & 0.82 & 0.38 \\
\hline Tube well & 178.43 & 175.83 & 25.22 & 25.97 & 15.27 & 14.92 \\
\hline SD & 10.48 & 8.59 & 1.50 & 1.56 & 0.82 & 0.89 \\
\hline
\end{tabular}

Table.3 Effect of sewage, dilute sewage and tube well water on enzyme of soil during mansoon and winter season

\begin{tabular}{|c|c|c|c|c|}
\hline \multirow[t]{2}{*}{ treatments } & \multicolumn{2}{|c|}{$\begin{array}{l}\text { alkaline phosphate enzyme activity ( } \mu \\
\text { ml PNP } \sec ^{-1} \text { ) }\end{array}$} & \multicolumn{2}{|c|}{$\begin{array}{l}\text { dehydrogenase enzyme activity } \\
\text { (P kat } \mathrm{kg}^{-1} \text { ) }\end{array}$} \\
\hline & Pre & Post & Pre & Post \\
\hline \multicolumn{5}{|c|}{ mansoon } \\
\hline Sewage & 16.81 & 13.99 & 16.39 & 12.58 \\
\hline SD & 0.99 & 0.85 & 0.91 & 0.79 \\
\hline $\begin{array}{l}\text { Dilute } \\
\text { sewage }\end{array}$ & 14.77 & 14.03 & 17.86 & 15.65 \\
\hline SD & 0.88 & 0.83 & 0.98 & 0.97 \\
\hline Tube well & 12.72 & 14.35 & 19.34 & 18.72 \\
\hline SD & 0.75 & 1.95 & 1.05 & 0.53 \\
\hline \multicolumn{5}{|c|}{ winter } \\
\hline Sewage & 12.50 & 11.56 & 12.77 & 12.49 \\
\hline SD & 0.67 & 0.71 & 0.63 & 1.08 \\
\hline $\begin{array}{l}\text { Dilute } \\
\text { sewage }\end{array}$ & 12.10 & 12.21 & 15.74 & 13.48 \\
\hline SD & 0.62 & 0.70 & 0.89 & 0.80 \\
\hline Tube well & 11.70 & 12.85 & 18.72 & 14.47 \\
\hline SD & 0.57 & 0.43 & 1.14 & 0.92 \\
\hline
\end{tabular}


Table.4 Correlation coefficient (r) between metallic cations in soil and biological properties of soil in sewage irrigated field

\begin{tabular}{|c|c|c|c|c|c|c|c|c|}
\hline $\begin{array}{l}\text { DTPA metallic cations / } \\
\text { biological properties of soil }\end{array}$ & $\mathbf{Z n}$ & $\mathbf{F e}$ & $\mathbf{C u}$ & Mn & $\mathbf{N i}$ & $\mathbf{P b}$ & Cd & $\mathrm{Cr}$ \\
\hline \multicolumn{9}{|l|}{ Mansoon } \\
\hline $\mathrm{MBC}$ & -0.466 & $-0.512 *$ & $-0.520 *$ & $-0.539 *$ & -0.357 & -0.213 & -0.403 & -0.462 \\
\hline MBP & -0.489 & $-0.551 *$ & $-0.573 *$ & $-0.566 *$ & -0.387 & -0.262 & -0.483 & -0.460 \\
\hline $\mathrm{MBN}$ & -0.386 & -0.436 & -0.475 & -0.449 & -0.223 & -0.214 & -0.329 & -0.367 \\
\hline Dehydrogenese & $-0.715 * *$ & $-0.777 * *$ & $-0.802 * *$ & $-0.813 * *$ & $-0.582 *$ & -0.420 & $-0.658 *$ & - \\
\hline Alkaline phosphatase & $-0.592 *$ & $-0.644 *$ & $-0.620 *$ & $-0.655^{*}$ & -0.390 & -0.271 & $-0.506^{*}$ & $-0.582 *$ \\
\hline \multicolumn{9}{|l|}{ Winter } \\
\hline MBC & $-0.550^{*}$ & $-0.517 *$ & $-0.576^{*}$ & $-0.547 *$ & $-0.528 *$ & -0.366 & -0.451 & -0.344 \\
\hline MBP & $-0.823 * *$ & $-0.802 * *$ & $-0.833 * *$ & $-0.824 * *$ & $-0.779 * *$ & $-0.629 *$ & $-0.714 * *$ & $-0.604 *$ \\
\hline $\mathrm{MBN}$ & $-0.523^{*}$ & -0.469 & $-0.556^{*}$ & $-0.500 *$ & -0.488 & -0.315 & -0.422 & -0.312 \\
\hline Dehydrogenase & $-0.647 *$ & $-0.611 *$ & $-0.669 * *$ & $-0.634 *$ & $-0.604 *$ & -0.446 & $-0.540 *$ & -0.431 \\
\hline Alkaline phosphatase & $-0.695 * *$ & $-0.652 *$ & $-0.713 * *$ & $-0.669 * *$ & $-0.633^{*}$ & -0.484 & $-0.587^{*}$ & -0.483 \\
\hline
\end{tabular}




\section{Dehydrogenase and alkaline phosphatase enzymes}

Activities of dehydrogenase and alkaline phosphatase enzymes were also lower in sewage and diluted sewage irrigated soil over tube well water (Table 3 ). This might be due to the build- up of heavy metal toxicity in soil. This reduced dehydrogenase activity in sewage irrigated soil was due to toxic effect. This is in conformity with the results of Rao et al., (1993) who reported lower activities of various enzymes in contaminated soils, irrigated with various industrial effluents.

Dehydrogenase activity decreased with increased extent of contamination. Heavy metal inhibits enzymatic reaction by bonding themselves to substrate, creating complex with substrate, blocking reactive functional group of enzymes (Mikanova, 2006). Negative correlation between dehydrogenase enzyme and heavy metal was also reported by Friedlova (2010). The results get support from the finding of Mikanova (2006) and Victor (2008)

It can be concluded that continuous use of sewage irrigation recorded, the amount of microbial biomass $\mathrm{C}, \mathrm{N}$ and $\mathrm{P}$ and soil enzyme activity declined irrigated soils as compared to tube well irrigated soils. Thus, it is justifiable to establish a municipal sewage treatments plant before such sewage water is diverted for the irrigation.

\section{References}

Antil, R.S. 2012. Impact of sewage and industrial effluents on soil-plant health. In: Industrial Waste Eds: Kuan-Yeow Show, www.intechopen.com, pp. 53-72.

Brookes, P.C., Landman, A., Pruden, G. and Jenkinson, D.S. 1985. Chloroform fumigation and the release of soil nitrogen: A rapid direct extraction method to measure microbial biomass nitrogen in soil. Soil Biol. Biochem., 17: 837-842.

Brookes, P.C., McGrath, S.P. and Heijnen, C. 1986. Metal residues in soils previously treated with sewage sludge and their effects on growth on growth and nitrogen fixation by blue green algae. Soil Biol. Biochem., 18: 345-353.

Brookes, P.C., Ocio, J. A. and Wu, J. 1990. The microbial biomass its measurement properties and role in nitrogen and carbon dynamics following substrate incorporation. Soil Microorganism, 35: 39-51.

Brookes, P.C., Powlson, D.S. and Jenkinson, D.S. 1982. Measurement of microbial biomass phosphorus in soil. Soil Biol. Biochem., 14: 319-329.

Casida, L.E., Jr. Klein, D.A. and Santoro, T. 1964. Soil dehydrogenase activity. Soil Sci., 98: 371-376.

Chander, K., Brooker, P.C. 1991a. Effect of heavy metals from past application of sewage sludge on microbial biomass and organic matter accumulation in a sandy loam and a silty loam Soil. Soil Boil.

Friedlova, M. 2010. The influence of heavy metals on soil biological and chemical properties. Soil and Water Res., 5: 21 27.

Hassan Dar, G.H. 1996. Effect of cadium and sewage sludge on soil microbial biomass and enzyme activities. Biores. Technol., 56: 141-145

Jinping, Longhua $\mathrm{Wu}$ Yougming $\mathrm{Na} \mathrm{Li}$, Liu Ling, Zhao Qiguo Zhang Lei and Christic Peter. 2010. Effect of multipal heavy metal contamination and repeated phytoextraction by Sedum plumbizincicola on soil microbial properties. European J. Soil Biol., 46: 18-26. 
Mikanova, O. 2006. Effect of heavy metals on some soil biological parameters. $J$. Geochem. Exploration, 88: 220-223.

Olsen, S.R., Cole, R.V. Watanabe, F.S. and Lean, L.A. 1954. Estimation of available phosphorus in soils by extraction with sodium bicarbonate.

Rao, A.C., Jain, B.L. and Fupta, I.C. 1993. Impact of taxtile industrial effluents on agricultural land- a case study. Indian $J$. Environ. Health Value, 35: 132-138.

Rao, D.L.N. 2007. Microbial diversity, soil health and sustainability. J. Indian Society of Soil Sci., 55: 392-403.

Srivastava, S.C. and Singh, J.S. 1988. C and P in the soil biomass of some tropical soils of India. Soil Biol. Biochem., 20; 743-747.

Tabatabai, M.A. and Bremner, J.M. 1969. Use of p-nitrophenyl phosphate for assay of soil phosphatase activity. Soil Biol. Biochem., 1: 301-307.
Tripathi, K.P., Harsh, L.N., Rao, A.V. and Kumar Praveen. 2006. Impact of polluted underground water from sewage of industrial effluents on soil properties and growth of Acacia Senegal. J. Indian Society of Soil Sci., 54: 101-105.

Vance, E.D., Brookes, P.C. and Jenkinson, D.S. 1987. An extraction method for measuring soil microbial biomass carbon. Soil Biol. Biochem., 19: 703707.

Victor, O.N., Reginald, A., Onyeagba, E.A. and Osita, U. 2008. Soil bacterial flora and enzymatic activities in $\mathrm{Zn}$ and $\mathrm{Pb}$ contaminated soil. Nigerian Society for Experimental Biol., 20: 77-84.

Yong, Z., Liu, S., Zheng, D. and Feng, S. 2006. Effects of cadmium zinc and lead on soil enzyme activities. J. Environ. Sci., 18: 1135-1141.

\section{How to cite this article:}

Kumawat, S.R., B.L. Yadav and Majumdar, S.P. 2017. Effect of Municipal Sewage on Soil Properties in the Vicinity of Jaipur City of Eastern Rajasthan. Int.J.Curr.Microbiol.App.Sci. 6(8): 1683-1689. doi: https://doi.org/10.20546/ijcmas.2017.608.202 